\title{
Effects of Fortification Stirred Yoghurt with Red Beet Powder (RBP) on Hypercholesterolemia Rats
}

\author{
Hanan S. Shalaby and Amira S. H. Hassenin
}

\begin{abstract}
The effects of stirred yoghurt fortified with red beet powder (RBP) on hypercholesterolemia rats were investigated during this study. Flavored yoghurts were evaluated for fibers and total phenolic compounds, identification of phenolic compounds of reed beet (RBP) powder. The chemical composition, physicochemical and rheological properties, color measurements and sensory evaluation of resultant yoghurt were evaluated. Thirty male rats were separated into 5 groups, group one negative control, as the other groups were organized hypercholesterolemia groups for two weeks after that, divided to 4 subgroups chase the $1^{\text {st }}$ subgroup present while, positive control, the $2^{\text {nd }}$ subgroup was fed on stirred yoghurt ,the $3^{\text {rd }}$ and the $4^{\text {th }}$ subgroups were given stirred yoghurt containing red beet powder at levels $(1 \%$ and $2 \%)$ respectively. The results revealed that beet root powder had $7.5 \%$ fiber and high amount of total phenolic $12.18 \mathrm{mg} / \mathrm{g}$. The level of phenolic compound in RBP there was a large difference with the identified components. The TS content of stirred yoghurt fortified with red beet powder (RBP) was increased by increasing the percentage added and increase the protein content. While the fat content decreasing. Generally, the higher per cent resulted in increasing viscosity value of yoghurt. Stirred yoghurt containing RBP had significant deferent of colour measurements and improved yoghurt properties for overall acceptability. Also, stirred yoghurt containing of RBP had significant different decreasing in organ weights (heart, liver and kidney) of the experimental rats. This study in all rats' groups fed on stirred yoghurt containing of RBP decreasing of blood lipid profile (T.G, T.C and LDL-c values) and significantly increased the HDL cholesterol. On the other hand, results illustrated of positive group significant increase in liver enzymes (ALT, AST) and (uric acid and creatinine) kidney functions compared with yoghurt containing of RBP which decreased. The histopathological examination of heart, liver and kidney demonstrated more or less normalized in the rat's groups fed on stirred yoghurt containing RBP compared to the positive group. Thus, the study descriptions that stirred yoghurt containing RBP have rich phenolic compounds and protect against hypercholesterolemia diseases.
\end{abstract}

Index Terms - Antioxidant activities, Hypercholerstermia, Phenolic compounds, Rat, Red beet, Yoghurt.

\section{INTRODUCTION}

Yoghurt is recognized a healthy promoting food and yoghurt adding to dietary fiber had more for a healthy effects and disease prevention such as the lowering of total cholesterol and increase of calcium bioavailability and preservation of gastrointestinal health [1], [16].

Published on September 23, 2020.

Hanan S. Shalaby, Zagazig University, Egypt.

Amira S. H. Hassenin, Zagazig University, Egypt.

(email: amm_microhass@yahoo.com)
Beet root (Beta vulgaris L.) is considered a health food because of vital composition such as vitamins, minerals, phenolics, carotenoids, ascorbic acids and betalains that encourage health. Beet root can be use of food manufacturing and food colorant and stabilizer in food products for example ice-cream, yogurts [35]. The red beet root is considered normal vegetable and widely consumed into numerous countries. The energy rate is moderate, but a rich of fiber and sugars [29]. Red beet roots are exceptional basis of folates, anti-oxidants, and vitamin A and B-complex vitamins such as niacin, pantothenic acid, pyridoxine and minerals [39]. Beta vulgaris var. rubra has numerous bioactive factors betain, betanin, vulgaxanthine, polyphenols, folic acid and special metal essentials like $\mathrm{Al}$, $\mathrm{B}, \mathrm{Ba}, \mathrm{Ca}, \mathrm{Cu}, \mathrm{Fe}, \mathrm{K}, \mathrm{Mg}, \mathrm{Mn}, \mathrm{Na}, \mathrm{Zn}$, as perform on the different physiological means [4].

Red beets have high in phenolic acids and is rich antioxidant and producing a normal coloring [10]. Adding to dietary fiber with stirred yoghurt increasing the different significantly the antioxidant activities and lowing the viscosity, [17],[19] demonstrated that yoghurt supplemented to vegetables and fruits is rich to improve the nutrients and health encourage effects.

Eating to yoghurt can be improve immune modulation by lowered prevalence of more diseases such as cancer and gastrointestinal disorders. This can enhance antibody making [8].

Consequently, the idea of this study was to evaluate the effect of the fortification of stirred yoghurt with red beet powder on chemical composition, physicochemical and rheological, color parameters and sensory properties of stirred yoghurt. The impact of consumption stirred yoghurt containing of RBP on serum lipid profile and possible health benefits of hypercholesterolemia rats was also studied.

\section{MATERIALS AND METHODS}

\section{A. Materials}

Fresh standardized fat buffalo's milk (3\% fat) was obtained from Dairy Technology Unit, Food Science Department, Faculty Agriculture, Zagazig University. All chemicals, and Kits were purchased from local distributors (Sigma chemical) El-Gmhoria company, Zagazig, Egypt. Red beets (Beta vulgaris L.) were collected from the local market, Zagazig city, Egypt.

\section{Starter Culture}

Yoghurt culture containing were Streptococcus salivarius subsp. thermophilus EMCC104 and Lactobacillus delbruekii subsp. bulgaricus EMCC1102 were obtained from the Microbiological Resources Center (MIRCEN), Faculty of Agriculture, Ain Shams University, Egypt. 


\section{B. Methods}

\section{Preparation of red beet powder $(R B P)$}

The leaves and stalk were separated from the beet roots (Beta vulgaris L.). Red beet can be clean with tap water, peeled carefully and slashed to small slices such as circles and then separately dry in air oven at $40{ }^{\circ} \mathrm{C}$ for $48 \mathrm{~h}$ to complete dryness and ground to powder.

\section{Stirred Yoghurt making fortified red beet powder} (RBP)

Fresh standardized milk ( $3 \%$ fat) can be heat at $90{ }^{\circ} \mathrm{C}$ for $5 \mathrm{~min}$ and frozen to $\left(40{ }^{\circ} \mathrm{C}\right)$. The milk was separated to 3 portions. The first portion was served as control without additives. The RBP was added at ratios of $1 \%,(\mathrm{~T} 1)$ and $2 \%$, (T2), then $3 \%$ of traditional starter culture addition to the mixtures and incubated at $45{ }^{\circ} \mathrm{C}$ until the shaping of the set composition then stirred and stored at refrigerator $\left(6 \pm 2{ }^{\circ} \mathrm{C}\right)$ for $8 \mathrm{~h}$. The amount of fiber was chosen according to [36].

\section{Identification of phenolic compounds using HPLC}

Phenolics components were identification and quantification by HPLC as explained by [8] and adapted by [17] This assay was conducted in Food Chem. Lab., Food Technol. Res. Institute, ARC, Egypt.

\section{Determination of chemical composition}

Fiber contents and total phenolic of RBP can be evaluation of the methods illustrated in [2]. While resultant stirred yoghurt from all treatments was chemically evaluate with total solids, fat, protein $\mathrm{pH}$, and acid value as explained in [3].

\section{Physicochemical and Rheological properties of yoghurt}

Viscosity: Viscosity of stirred yoghurt samples were determined by the method of [7] using Rotational Viscometer, model 5437. Results were expressed as CPS.

Syneresis was determined according to [7], The syneresis index (\%) was calculated by $\mathrm{mL}$ of whey per $100 \mathrm{~mL}$ of each first sample.

Measurement of colour: Determination of colour of each product was measured at Hunter optical sensor devise. Colour stricture $\mathrm{L}^{*}$ shows amount of lightness, a* shows the amount of redness and $b^{*}$ shows the amount of yellowness to blueness [47].

Sensory evaluation: Fifteen qualified panelists from the team member of Food Science Department, Zagazig University, Faculty Agriculture, Egypt used the excellence rating point tag for the assessment of flavour (50 points) body of texture (40 points) and appearance (10 points). Yoghurt treatments were organoleptically examined after refrigeration according to [32].

Animal feeding experiment: The basil pellet diets were got from the central rats' house of the National Research Center, Dokki, Giza, Egypt. This normal diet consisted of $20 \%$ protein (casein), 5\% fiber (cellulose), $10 \%$ sucrose, $4.7 \%$ corn oil, $0.2 \%$ choline chloride, $0.3 \%$ methionin, $1 \%$ vitamin mixtures, $3.5 \%$ salt mixture. The remainder was corn starch. Salt and vitamin mixtures were prepared according to [33], [12].

High-cholesterol diet: The basil pellet diets which described above was grinded and supplemented with; $0.50 \%$ buffalo fat, $1 \%$ cholesterol and $0.25 \%$ biles acid.

6. Biological experimental plan
Thirty healthy adult male albino rats weighting (100$105 \mathrm{~g}$ ) can be divided into five groups, six rats per each. The adaptation period containing to seven days, the first group sustained feeding on the basal diet and present by negative control group (G1). The following four groups were fed on high cholesterol diet two weeks and were divided to group (G2) can be hypercholesterolemia rats fed on normal diet and identified a positive control. The third group can be hypercholesterolemia rats fed on $10 \%$ stirred yoghurt without any additives (G3). The fourth group can be hypercholesterolemia rats fed on $10 \%$ stirred yoghurt containing 1\% RBP (G4) and the fifth group can be hypercholesterolemia rats fed on $10 \%$ stirred yoghurt containing $2 \% \mathrm{RBP}(\mathrm{G} 5)$.All groups were fed for 6 weeks.

\section{Biochemical analyses of blood samples}

Blood samples were collected from rats using $5 \mathrm{ml}$ syringe by cardiac puncture. It was centrifuged at $3000 \mathrm{rpm}$ for 15 min for separate serum. Total cholesterol, HDL-C and triglyceride rats were expected in serum as described by [13]. LDL -cholesterol was deliberated the way of [37] Liver enzymes, alanine amino transferase (ALT), aspartate amino transferase(AST) and total protein were assessment as reported by [48] Kidney functions were determined in serum creatinine and blood urea were determined as shown by [48].

\section{Histopathological examination}

Fixation and tissue processing: liver, kidney and heart were giving directly after sacrificing the rats and immersed in $10 \%$ buffered impartial formalin solution, the fixed specimens after that trimmed, washed and dehydrated in bedded, in paraffin slice into sections of 4-6 microns thickness and discoloured with haematoxylin and Cosin blemish according to [44] Histopathological studies were monitored by microscopic examination of paraffin embedded slices of liver, kidney and brain from rats. All sections are examined at 400X magnification using a light microscope in Zagazig University, Faculty of Veterinary, Egypt.

\section{Statistical Analysis}

The obtained results were statistically experienced with examination of multi variance ANOVA and discriminative trial. ANOVA meaning and Roy test both with 0.05 significance level were utilized as Unitarian statistical measures to evaluated significant differences among means [43].

\section{RESULTS AND DISCUSSION}

\section{A. Fibers (\%) and Total phenolic compounds (TPC mg/g) with Red Beet Powder (RBP)}

Fibers (\%) and total phenolic compounds (TPC) of RBP are shown in (Table 1). The results indicated that RBP was $7.5 \%$ of fiber and $12.18 \mathrm{mg} / \mathrm{g}$ of total phenolic. These data are in agree with those obtained with [41]. Total phenols in beet root, consider rich sources of antioxidants. Therefore, red beet powder is the excellent basis of bioactive compounds which have increase ant oxidative possessions. Previous studies [45] have indicated that the contents of antioxidants found to processed red beet was high, which because of its free radical scavenging resulted reserve of 
lipid peroxidation and had ability to raise antioxidant activity.

TABLE 1: FIBERS AND TOTAL PHENOLIC COMPOUNDS (TPC) CONTENTS

\begin{tabular}{c|c}
\multicolumn{2}{c}{ OF RED BEET POWDER (RBP) } \\
\hline PARAMETER & RBP \\
\hline FIBERS $(\%)$ & 7.5 \\
TPC(MG/G) & 12.18 \\
\hline
\end{tabular}

\section{B. Identification of phenolic compounds in Red Beet Powder (RBP)by HPLC}

The phenolic compounds of the red beet powder were assessed using HPLC are presented in Table 2. The level of phenolic compounds in RBP showed large difference with the known components. Phenolic compounds identified into RBP levels from 0.0562 to $325.0395 \mathrm{ppm}$. Phenolic compounds were identified in red beet powder were Coumaric acid, Quercetin, Kaempferol, Naphthaline and Resorcinol acid. The obtained results are similar to those reported by [41], [34]. Beet roots powder have important bioactive agents (betaine and polyphenols), which included a vary of physiologic factors [46]. The present study agrees with [41], who found that phenolic compounds by antioxidants have a lot of possible pathways for example free radical-scavenging, oxygen radical absorbance.

TABLE 2: IDENTIFICATION OF PHENOLIC COMPOUNDS IN RED BEET

\begin{tabular}{c|c}
\multicolumn{2}{c}{ POWDER BY HPLC } \\
\hline Compounds & Concentration $(\mathrm{ppm})$ \\
\hline Coumarin acid & 325.0395 \\
Ferulic acid & ND \\
Resorcinol & 0.0562 \\
Quercetin & 136.0987 \\
Kaempferol & 43.2809 \\
Naphthaline & 0.1974 \\
Phenantherine & ND \\
\hline
\end{tabular}

$\mathrm{ND}=$ Not detected

\section{Chemical composition of stirred yoghurt containing of red beet powder $(R B P)$}

Table 3 shows the chemical composition of stirred yoghurt containing of red beet root powder (RBP). The chemical analysis reveals that control stirred yoghurt samples had the lowest total solids (TS) and it was differed from all yoghurt treatments. While yoghurt containing $2 \%$ red beet powder (T2) exhibited the highest (TS) content, followed by yoghurt blended with $1 \%$ red beet powder (T1). The TS content of yoghurt containing natural additives (RBP) increased by increasing the percentage added. Also, Table 3 show that, the control yoghurt (C) had slight increase in the fat content compared with other samples. Conversely, adding natural to milk does not influence the fat content of the resulting yoghurt where found not different significant. Furthermore, data shows that the yoghurt containing RBP had slight increase in the total protein (T1 and T2) compared with control yoghurt (C). The total protein of yoghurt with RBP a little high by increasing the percentage added. These results agree with those explanation by [20] who found that their alterations in the total solid, protein and fat green tea or Moringa oleifera leaves extracts yoghurt were no.
TABLE 3: CHEMICAL COMPOSITION OF STIRRED YOGHURT CONTENTING OF RED BEET ROOT POWDER (RBRP)

\begin{tabular}{|c|c|c|c|}
\hline SAMPLE & $\begin{array}{c}\text { TOTAL SOLIDS } \\
(\%)\end{array}$ & TOTAL FAT (\%) & $\begin{array}{c}\text { TOTAL PROTEIN } \\
(\%)\end{array}$ \\
\hline $\mathrm{C}$ & $11.169 \pm 0.9950 \mathrm{C}$ & $3.421 \pm 0.1528 \mathrm{~A}$ & $3.523 \pm 0.1002 \mathrm{C}$ \\
\hline $\mathrm{T} 1$ & $12.126 \pm 1.0947 \mathrm{~B}$ & $3.220 \pm 0.1704 \mathrm{~A}$ & $3.7640 \pm 0.1217 \mathrm{~B}$ \\
\hline $\mathrm{T} 2$ & $12.750 \pm 1.1187 \mathrm{~A}$ & $3.154 \pm 0.1782 \mathrm{~A}$ & $3.776 \pm 0.0586 \mathrm{~A}$ \\
\hline LSD & 0.2868 & 0.234 & 0.1018 \\
\hline \multicolumn{4}{|c|}{$\begin{array}{l}\text { Values with different letters in the same column are significantly different } \\
(\mathrm{P} \leq 0.05) \\
\mathrm{C} \text { : control stirred yoghurt } \mathrm{T} 1 \text { : Stirred yoghurt containing } 1 \% \text { red beet } \\
\text { powder. } \\
\text { T2: Stirred yoghurt containing } 2 \% \text { red beet powder. }\end{array}$} \\
\hline
\end{tabular}

\section{Physicochemical and Rheological properties of stirred yoghurt}

Viscosity and syneresis of stirred yoghurt containing red beet powder are shown in Table 4. Yoghurt samples containing RBP had significantly high viscosity than control yoghurt. The increase was comparative to the rate of additives. This may because of the addition of beet root powder usually increased the viscosity of the products have condensed water-binding capacity of proteins. These results agree with those explanation by [23], [31], [41].

[1], [6] reported that fiber concentration modified yoghurt rheology and the addition to yoghurt (1 g orange fiber / $100 \mathrm{ml}$ ) decreased syneresis compared to control sample.

\section{E. $p H$ values of stirred yoghurt containing RBP}

Table 4 revealed that the highest $\mathrm{pH}$ value was found in control yoghurt then yoghurt containing RBP. This decrease might be attributed to the resident fermentation change. That agree with [18] who found no different significant variation in control yoghurt and fortified yoghurt when adding carrot juice to yoghurt.

Acidity values of the stirred yoghurt containing red beet powder are presented in Table 5. The acidity increasing in stirred yoghurt containing red beet. This may be due to the chemical composition of RBP itself that helps fermentation so fast although there was no significant difference. [6] reported that the ability of various fibers to raise the acidity of fermented foods.

TABLE 4: PHYSICOCHEMICAL AND RHEOLOGICAL PROPERTIES (VISCOSITY, SYNERESIS, PH AND ACIDITY OF STIRRED YOGHURT CONTAINING RBP

\begin{tabular}{c|c|c|c|c}
\hline Treatments & $\begin{array}{c}\text { Viscosity } \\
(\mathrm{CPS})\end{array}$ & $\begin{array}{c}\text { Syneresis } \\
(100 \mathrm{ml})\end{array}$ & $\mathrm{PH}$ & $\begin{array}{c}\text { Acidity } \\
\text { value }\end{array}$ \\
\hline $\mathrm{C}$ & $2750 \pm 100 \mathrm{C}$ & $15.9 \pm 0.50 \mathrm{~B}$ & $4.4350 \pm 0.1 \mathrm{~A}$ & $1.095 \pm 0.1 \mathrm{~A}$ \\
T1 & $3200 \pm 100 \mathrm{~B}$ & $15.5 \pm 0.50 \mathrm{~B}$ & $4.159 \pm 0.1 \mathrm{C}$ & $1.115 \pm 0.1 \mathrm{~A}$ \\
T2 & $3699.7 \pm 100 \mathrm{~A}$ & $14.900 \pm 0.2 \mathrm{~A}$ & $4.383 \pm 0.1 \mathrm{~B}$ & $1.123 \pm 0.1 \mathrm{~A}$ \\
LSD & 0.7557 & 1.1852 & 1.5 & 0.2618 \\
\hline
\end{tabular}

Values with different letters in the same column are significantly different $(\mathrm{P} \leq 0.05)$.

C: Control stirred yoghurt T1: Stirred yoghurt containing $1 \%$ red beet powder.

T2: Stirred yoghurt containing $2 \%$ red beet powder.

\section{$F$. Colour measurements of stirred yoghurt containing $R B P$}

Results presented in Table 5 shows that stirred yoghurt containing 2\% RBP had the highest a* value (3.90) which put it in the red zone, and this was a significantly different, but control yoghurt had the highest $b^{*}$ value (10.55) which indicates degree of yellowness to blueness. [42] proved that 
the brownish colour for apple fiber added to yoghurt would create it essential to put in flavour components to modify yoghurt formulation to match consumer preferences. [22] fortified yoghurt with date fibers which gave decrease $\mathrm{L}^{*}$ and increase $a^{*}$ values and this was a significantly affect by this kind of fortification.

TABLE 5: COLOUR MEASUREMENTS OF STIRRED YOGHURT CONTAINING RBP

\begin{tabular}{c|c|c|c}
\hline \multirow{2}{*}{ Treatment } & \multicolumn{3}{|c}{ Colour } \\
\cline { 2 - 4 } & $\mathrm{L}^{*}$ & $\mathrm{~A}^{*}$ & $\mathrm{~B}^{*}$ \\
\hline $\mathrm{C}$ & $50.390 \mathrm{~B}$ & $3.250 \mathrm{G}-$ & $10.55 \mathrm{D}$ \\
$\mathrm{T} 1$ & $46.94 \mathrm{C}$ & $-3.770 \mathrm{I}$ & $7.340 \mathrm{E}$ \\
$\mathrm{T} 2$ & $59.480 \mathrm{~A}$ & $-3.907 \mathrm{H}$ & $6.973 \mathrm{~F}$ \\
LSD & 0.0313 & 0.0360 & 0.0360 \\
\hline
\end{tabular}

Values with different letters in the same column are significantly different $(\mathrm{P} \leq 0.05)$.

C: Control stirred yoghurt $\mathrm{T}_{1}$ : Stirred yoghurt containing $1 \%$ red beet powder.

$\mathrm{T}_{2}$ : Stirred yoghurt containing $2 \%$ red beet powder.

$\mathrm{L}^{*}$ (lightness) $\mathrm{a}^{*}$ (red/greenness) $\mathrm{b}^{*}$ (yellow/blueness).

\section{G. Sensory evaluation of stirred yoghurt containing red beet powder $(R B P)$}

Sensory test was performed to examine the acceptance of the stirred yoghurt containing RBP. As shown in Table 6, the samples revealed that stirred yoghurt had the highest preferred scores all sensory evaluation panelists. Increasing red beet powder in stirred yoghurt caused increases in panelist scores. All yoghurt treatments were accepted by panelists. The adding improved yoghurt possessions and general acceptability. These results agree with that shown by [22].

[10] showed that containing red beet root to biscuits raise acceptability and nutritional rates and improve liver function enzymes to content of antioxidant.

TABLE 6: SENSORY EVALUATION OF STIRRED YOGHURT CONTAINING RED BEET POWDER (RBP)

\begin{tabular}{c|c|c|c|c}
\hline \multirow{2}{*}{ Sample } & $\begin{array}{c}\text { Appearan } \\
\text { ce }(10)\end{array}$ & $\begin{array}{c}\text { Flavour } \\
(50)\end{array}$ & $\begin{array}{c}\text { Body and } \\
\text { texture }(40)\end{array}$ & $\begin{array}{c}\text { Total } \\
(100)\end{array}$ \\
\hline \multirow{2}{*}{$\mathrm{C}$} & $9.400 \pm$ & $46.500 \pm$ & $38.80 \pm$ & $94.500 \pm$ \\
& $0.1633 \mathrm{~A}$ & $0.6191 \mathrm{~A}$ & $0.3590 \mathrm{~A}$ & $0.7341 \mathrm{~A}$ \\
$\mathrm{~T} 1$ & $8.00 \pm$ & $44.400 \pm$ & $38.600 \pm$ & $89.700 \pm$ \\
& $0.298 \mathrm{~B}$ & $1.292 \mathrm{~A}$ & $0.618 \mathrm{~A}$ & $1.795 \mathrm{~B}$ \\
$\mathrm{~T} 2$ & $8.50 \pm$ & $45.300 \pm$ & $39.400 \pm$ & $93.00 \pm$ \\
& $0.372 \mathrm{~B}$ & $1.333 \mathrm{~A}$ & $0.4989 \mathrm{~A}$ & $1.3416 \mathrm{~B}$ \\
LSD & 0.8451 & 3.2801 & 1.4605 & 3.9511 \\
\hline
\end{tabular}

H. Impact of feeding stirred yoghurt containing RBP on the heart, liver, and kidney organs weight of rats

From Table 7, it could be observed that positive control group of rats had significant high in heart, liver and kidney weights comparing with negative control group and all other treatments. Also, it could be observed that the lowest weights of organs were in group rats fed on $2 \%$ of RBP where had the significant different decreasing in organ weights. Also, in this study increasing RBP ratio due to decrease organ weights.

TABLE 7: IMPACT OF FEEDING STIRRED YOGHURT CONTAINING RBP ON THE HEART, LIVER AND KidNEY ORGAN WeIGHTS OF RATS AT THE END OF FEEDING

\begin{tabular}{c|c|c|c}
\hline $\begin{array}{c}\text { Rats } \\
\text { Group }\end{array}$ & $\begin{array}{c}\text { Heart } \\
\text { (weight g) }\end{array}$ & $\begin{array}{c}\text { Kidney } \\
\text { (weight g) }\end{array}$ & $\begin{array}{c}\text { Liver } \\
\text { (weight g) }\end{array}$ \\
\hline G1 & $0.8438 \pm 0.028 \mathrm{AB}$ & $2.157 \pm 0.044 \mathrm{~A}$ & $9.1109 \pm 0.222 \mathrm{AB}$ \\
G2 & $0.9070 \pm 0.026 \mathrm{~A}$ & $2.139 \pm 0.047 \mathrm{~A}$ & $9.667 \pm 0.210 \mathrm{~A}$ \\
G3 & $0.7030 \pm 0.027 \mathrm{C}$ & $1.853 \pm 0.104 \mathrm{~B}$ & $8.837 \pm 0.176 \mathrm{~B}$ \\
G4 & $0.7892 \pm 0.0262 \mathrm{~B}$ & $1.998 \pm 0.095 \mathrm{AB}$ & $9.517 \pm 0.326 \mathrm{~A}$ \\
G5 & $0.6758 \pm 0.019 \mathrm{C}$ & $1.8495 \pm 0.044 \mathrm{~B}$ & $8.566 \pm 0.244 \mathrm{~B}$ \\
L.S.D & 0.0840 & 0.2615 & 0.5862 \\
\hline
\end{tabular}

Values with different letters in the same column are significantly different $(\mathrm{P} \leq 0.05)$.

-Ve: Negative control group.

+ Ve: Positive control group.

G1: Un-treated rats (negative control group) fed on feeding normal all experiment period.

G2: Hypercholesterolemia rats fed on feeding normal (positive control group).

G3: Hypercholesterolemic rats fed on stirred yoghurt without any additives G4: Hypercholesterolemia rats fed on stirred yoghurt 1\% RBP.

G5: Hypercholesterolemia rats fed on stirred yoghurt $2 \%$ RBP.

\section{Impact of feeding stirred yoghurt containing RBP on serum lipid profile of hypercholesterolemia rats}

Impact of feeding stirred yoghurt contenting RBP on serum lipid profile of hypercholesterolemia rats is presented in Table 8. This study indicated that the all groups rats fed on stirred yoghurt containing RBP showed decreasing of blood lipid profile (T.G, T.C and LDL-c values) and significantly increased the level of HDL cholesterol. Triglycerides in positive group rats was significantly increasing compared with rats group fed on stirred yoghurt containing RBP groups $(\mathrm{p}<0.05)$. On the inverse that HDLcholesterol was significantly better raise in rats fed on stirred yoghurt containing of RBP groups compared with positive group $(\mathrm{p}<0.05)$. There was virtually significantly difference in LDL and VLDL-cholesterol among groups.

TABLE 8: IMPACT OF FEEDING STIRRED YOGHURT RBP ON BLOOD LIPID PROFILE OF HYERCHOLESTERMIA IN RATS

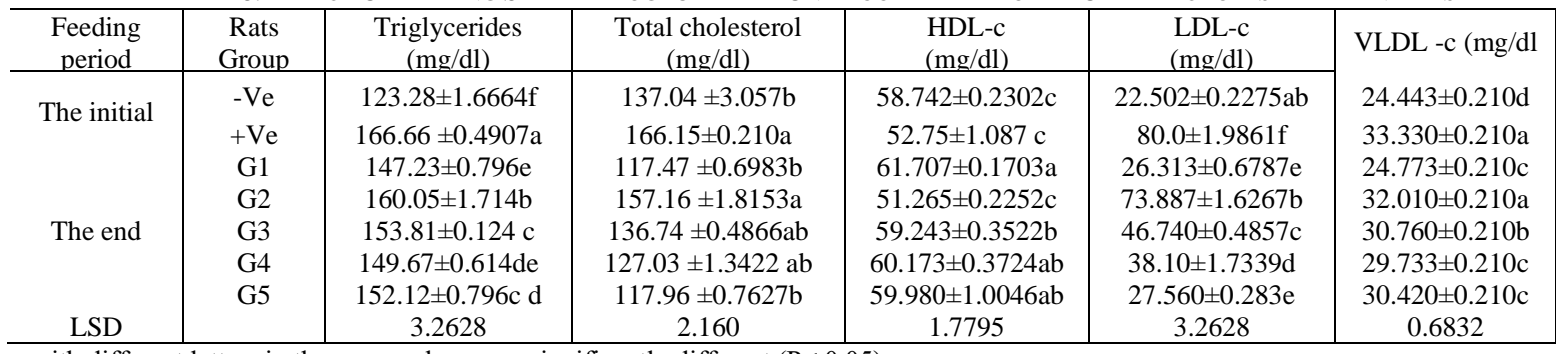

Values with different letters in the same column are significantly different $(\mathrm{P} \leq 0.05)$.

-Ve: Negative control group.

+ Ve: Positive control group.

G1: Un-treated rats (negative control group) fed on feeding normal all experiment period.

G2: Hypercholesterolemia rats fed on feeding normal (positive control group).

G3: Hypercholesterolemic rats fed on stirred yoghurt without any additives.

G4: Hypercholesterolemia rats fed on stirred yoghurt $1 \%$ RBP.

G5: Hypercholesterolemia rats fed on stirred yoghurt $2 \%$ RBP. 
These results agree with [30] who designated that the raise of total cholesterol rate and triglyceride by rats fed on diet with cholesterol compare to feeding rats beetroot crisps it was because of hypocholesterolemic act of dietary crisps in the dyslipidaemic groups [40]. At the inter face polar antioxidants can be acting any free radical scavengers because of their hydrogen-donating capability. These results agree with that reported by [39], who reported that reed beet decreased the total cholesterol and increased the HDL-c. These results agree with that reported by [24]. The stirred yoghurt containing of beet root had decreased the profile lipids because of flavanoids on cholesterol metabolism and saponins were appeared to be the central elements of beet root. Studies representing saponins from some medicinal plants condensed the triglycerides and cholesterol values in rats and flavonoids are measured as active values to a lot of medicinal plants and natural foods with positive result on human health [38].

$J$. Impact of feeding stirred yoghurt contenting of RBP on liver and kidney functions of hypercholesterolemia rats

From the data in Table 9 it might be appeared that the rats fed yoghurt containing RBP were characterized by increasing significantly serum total protein compared with the positive group of rats. This increase can be increase protein contents of yoghurt containing RBP. On the other hand, results illustrated of positive group showed significant increase in liver enzymes (ALT, AST) and (uric acid and creatinine) kidney functions compare with yoghurt containing of RBP that was decreased. Where, yoghurt RBP contains several bioactive agents as polyphenols. The best groups were yoghurt RBP at ratio $2 \%$ which had lowest value of ALT, AST and creatinine. The feeding rats on stirred yoghurt containing $2 \% \mathrm{RBP}$ prevented the rise of mean ALT, and activities and creatinine. These results are according to earlier studies [24], [25], [38]. Those illustrated that polyphenols stopped the raise in serum ALT and AST values.

[27] indicated that using of red beet root (Beta vulgaris L.) as a medicine for liver and kidney diseases, for inspiration of the immune systems. [20], [10] showed that Beta vulgaris extract decreased of enzyme activities levels, where lowing the serum AST and ALT, because of its chemical contents.

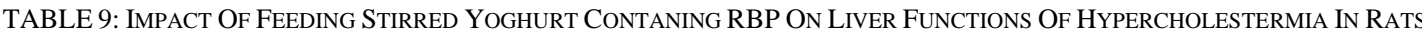

\begin{tabular}{c|c|c|c|c|c|c}
\multicolumn{2}{c}{ TABLE 9: IMPACT OF FEEDING STIRRED YOGHURT CONTANING RBP ON LIVER FUNCTIONS OF HYPERCHOLESTERMIA IN RATS } \\
\hline $\begin{array}{c}\text { Feeding } \\
\text { period }\end{array}$ & $\begin{array}{c}\text { Rats } \\
\text { Groups }\end{array}$ & $\begin{array}{c}\text { Total protein } \\
(\mathrm{g} / \mathrm{dl})\end{array}$ & $\begin{array}{c}\text { ALT } \\
(\mathrm{U} / \mathrm{L})\end{array}$ & $(\mathrm{U} / \mathrm{L})$ & $\begin{array}{c}\text { Urea } \\
(\mathrm{mg} / \mathrm{dl})\end{array}$ & $\begin{array}{c}\text { Creatinine } \\
(\mathrm{mg} / \mathrm{dl})\end{array}$ \\
\hline \multirow{5}{*}{} & $-\mathrm{Ve}$ & $\begin{array}{c}7.4533 \\
\pm 2.1090 \mathrm{ab}\end{array}$ & $62.333 \pm 5.8916 \mathrm{a}$ & $51.33 \pm 1.3333 \mathrm{a}$ & $1.143 \pm 0.0203 \mathrm{~cd}$ & $22.470 \pm 0.969 \mathrm{c}$ \\
\cline { 2 - 7 } & $+\mathrm{Ve}$ & $7.0133 \pm 2.15 \mathrm{a}$ & $75.33 \pm 2.4012 \mathrm{ab}$ & $64.667 \pm 1.6667 \mathrm{a}$ & $1.2667 \pm 0.0176 \mathrm{ab}$ & $39.613 \pm 0.5021 \mathrm{a}$ \\
\hline & $\mathrm{G} 1$ & $7.26 \pm 0.6983 \mathrm{~d}$ & $47.667 \pm 2.6034 \mathrm{~b}$ & $47.333 \pm 2.6034 \mathrm{~b}$ & $1.1833 \pm 0.0384 \mathrm{bc}$ & $40.040 \pm 0.0520 \mathrm{a}$ \\
\cline { 2 - 7 } & $\mathrm{G} 2$ & $7.133 \pm 1.8153 \mathrm{~cd}$ & $75.333 \pm 1.6667 \mathrm{a}$ & $66.33 \pm 1.6667 \mathrm{a}$ & $1.0387 \pm 0.0307 \mathrm{~d}$ & $39.597 \pm 0.2270 \mathrm{a}$ \\
\cline { 2 - 7 } & $\mathrm{G} 3$ & $7.373 \pm 0.4866 \mathrm{bc}$ & $65.333 \pm 1.6667 \mathrm{a}$ & $29.667 \pm 1.6667 \mathrm{~cd}$ & $1.0733 \pm 0.0433 \mathrm{~d}$ & $38.770 \pm 0.1308 \mathrm{a}$ \\
\cline { 2 - 7 } & $\mathrm{G} 4$ & $7.483 \pm 1.3422 \mathrm{~cd}$ & $\begin{array}{c}59.333 \\
\pm 1.4530 \mathrm{ab}\end{array}$ & $19.0 \pm 1.4530 \mathrm{~d}$ & $1.2033 \pm 0.0491 \mathrm{bc}$ & $26.113 \pm 0.5976 \mathrm{~b}$ \\
\hline & $\mathrm{G} 5$ & $7.773 \pm 0.7627 \mathrm{~cd}$ & $47.667 \pm 2.6034 \mathrm{~b}$ & $19.32 \pm 2.6034 \mathrm{~d}$ & $1.3633 \pm 8.819 \mathrm{a}$ & $25.120 \pm 0.7153 \mathrm{~b}$ \\
\hline
\end{tabular}

Ve: Negative control group.

+ Ve: Positive control group.

G1: Un-treated rats (negative control group) fed on feeding normal all experiment of period.

G2: Hypercholesterolemia rats fed on feeding normal (positive control group).

G3: Hypercholesterolemic rats fed on stirred yoghurt without any additives.

G4: Hypercholesterolemia rats fed on stirred yoghurt $1 \%$ RBP.

G5: Hypercholesterolemia rats fed on stirred yoghurt $2 \%$ RBP

\section{K. Histological examination}

The beneficial effects of hypercholesterolemia rats fed on stirred yoghurt contenting of RBP were confirmed by histopathological examination of the heart, liver and kidney are shown in Fig. 1-3 respectively.

Microscopically examination of rats' heart in positive control group, appeared in Fig 1 a moderate number of the cardiomyocytes showed hyaline degeneration and or fatty degeneration. The latter was very prominent in the sub endocardial cells particularly of the atrioventricular valves. While in Photo $1 \mathrm{~b}$ heart of hypercholesterolemia rats fed on stirred yoghurt without any additives was mild interstitial edema, hyaline degeneration and vacuolations in the intemial and sub intemal cells of the coronary blood vessels. Some of the latter showed mucoid changes. On the observed Fig $1 \mathrm{c}$, heart of hypercholesterolemia rats fed on stirred yoghurt containing 1\% RBP section showed perivascular edema, vacuolation of the coronary vascular wall cells and hyaline degeneration in some cardiomyocytes. While Fig. 1 d sections from heart of hypercholesterolemia rats fed on stirred yoghurt 2\% RBP, showing only interstitial edema in some parts of the ventricles and vacuolation of coronary vascular wall, and normal nearly histological structure.

Fig 2 a. Liver sections of rats in positive control group revealed mild congestion of hepatic blood vessels, portal round cells infiltration beside hydropic degeneration and fatty changes in a few hepatocytes. Moreover Fig 2 b, liver of hypercholesterolemia rats fed on stirred yoghurt without any additives most of the hepatic parenchyma were apparently normal, however a few hepatocytes showed hydropic and or vacuolar degeneration. Fig 2 c, liver sections of hypercholesterolemia rats fed on stirred yoghurt $1 \%$ RBP showed apparently normal histomorphological structures, a part of a few cells which showed vacuolar degeneration. Mild portal congestion, edema and biliary proliferation were also seen. Fig $2 \mathrm{~d}$. liver sections of hypercholesterolemia rats fed on stirred yoghurt $2 \%$ RBP, showed mild congestion of portal blood vessels, edema and biliary proliferation. Moderate number of hepatocytes showed hydropic degeneration. The kupffer cells were 
prominent and normal nearly histological structure. These results agree [26], [25], [28], [34].

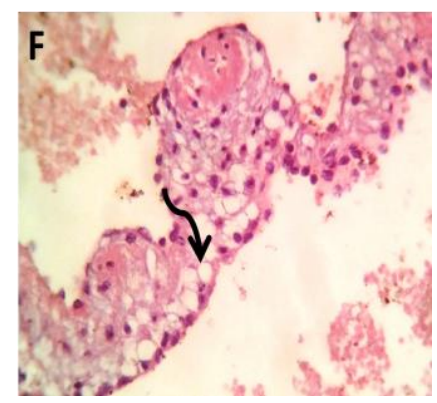

a)

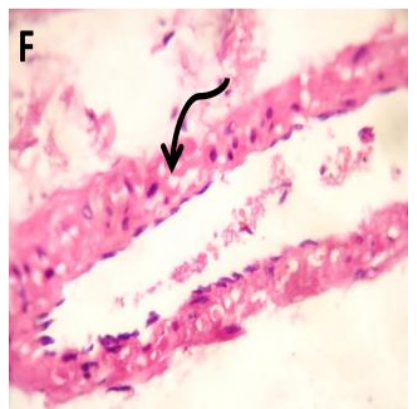

c)

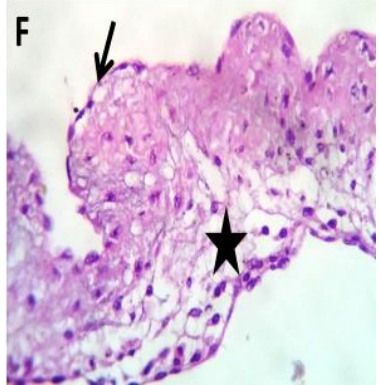

b)

d)

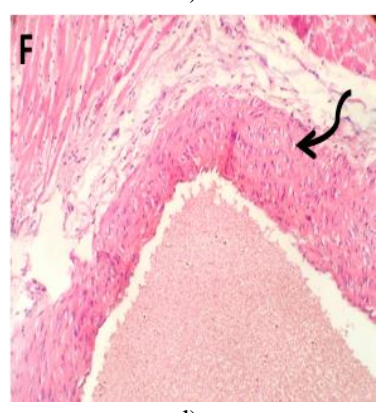

Fig. 1. a) Heart of hypercholesterolemia rats fed on normal feeding (positive control);

b) Heart of hypercholesterolemia rats fed on stirred yoghurt without any additives;

c) Heart of hypercholesterolemia rats fed on stirred yoghurt $1 \% \mathrm{RBP}$ d) Heart of hypercholesterolemia rats fed on stirred yoghurt $2 \%$ RBP.

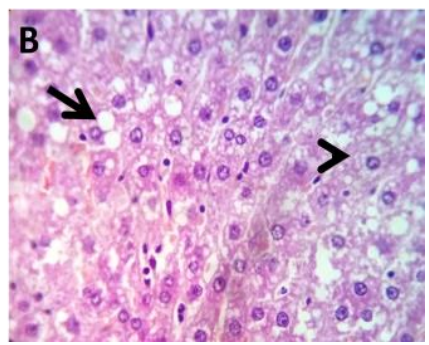

a)

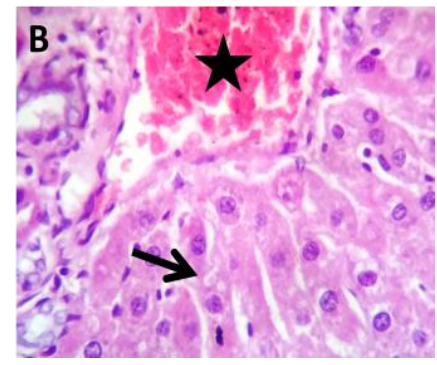

c)

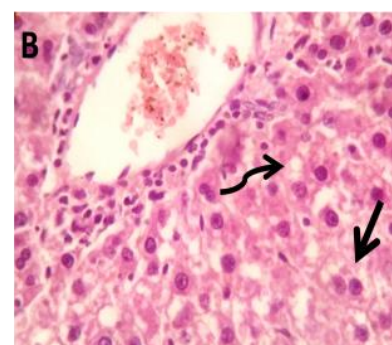

b)

d)

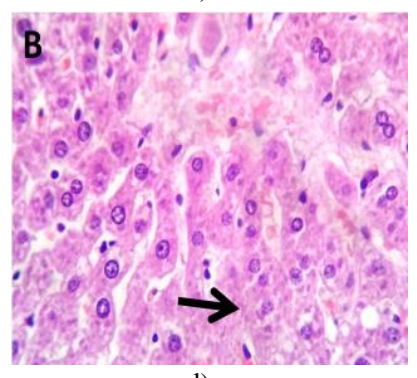

Fig. 2. a) liver of hypercholesterolemia rats fed on normal feeding (positive control);

b) liverof hypercholesterolemia rats fed on stirred yoghurt without any additives;

c) liver of hypercholesterolemia rats fed on stirred yoghurt $1 \% \mathrm{RBP}$;

d) liver of hypercholesterolemia rats fed on stirred yoghurt $2 \% \mathrm{RBP}$.

Fig 3 a. rats Kidney in positive control group moderate number of the renal tubular epithelium in the cortex and medulla showed degenerative changes mainly hydropic degeneration and necrotic changes beside hypocellularity of some glomeruli. Hyaline casts and accumulation of protenacious materials in the glomerular spaces were also seen. The renal pelvis revealed focal sloughing of the epitheliual lining. Fig 3 b kidney rats hypercholesterolemia fed on stirred yoghurt without any additives moderate number of the cortical and medullar tubules showed hydropic and vacuolar degeneration. The blood vessels were mildly congested, and the glomeruli were apparently normal Kidney Fig 3 c, hypercholesterolemia rats fed on stirred yoghurt $1 \%$ RBP revealed apparently normal most of the glomeruli and tubules, however, a few of tubular epithelium showed hydropic degeneration and necrotic changes. In addition, Fig 3 d, Kidney sections hypercholesterolemia rats fed on stirred yoghurt 2\% RBP, revealed mild congestion of the renal blood vessels, hydropic degeneration or necrotic changes in a few renal tubular epithelium. Most of the renal tubules and glomeruli were apparently normal. This results with agree [25], [28].

Consumption of red beet as defend against diseases and red beet is source rich by phenolic acids and antioxidant ability [9].

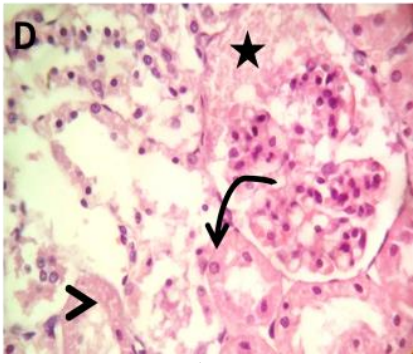

a)

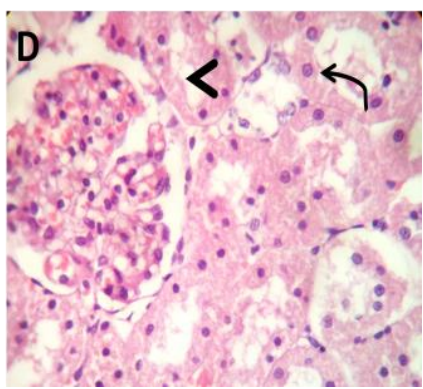

c)

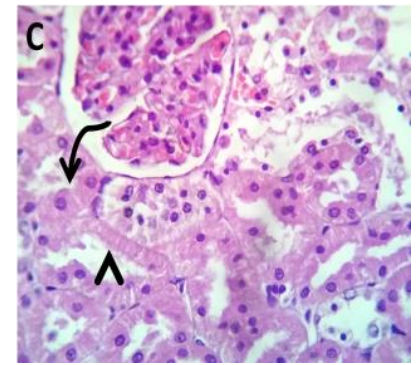

b)

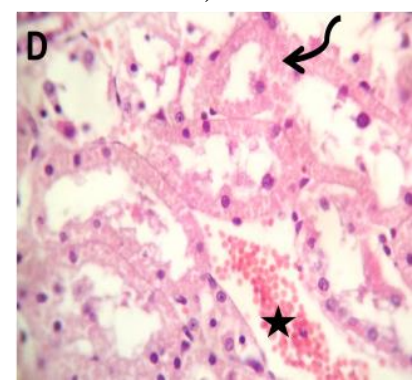

d)
Fig. 3. a) Kidney of hypercholesterolemia rats fed on normal feeding (positive control);

b) kidney of hypercholesterolemia rats fed on stirred yoghurt without any additives;

c) kidney of hypercholesterolemia rats fed on stirred yoghurt $1 \% \mathrm{RB}$;

d) kidney of hypercholesterolemia rats fed on stirred yoghurt $2 \%$ RBP.

\section{REFERENCES}

[1] Alaa H. Ibrahim and Khalifa S. A. (2015). Improve Sensory Quality and Textural Properties of Fermented Camel's Milk By Fortified With Dietary Fiber J. Am. Sci. 11(3).

[2] AOAC. (2005). Association of Official Analytical Chemists official method of analysis. (18th Ed.), Benjamin Franklin Station Washington, D.C.

[3] AOAC. (2007). Association of Official Analytical Chemists official method of analysis. (18th Ed.), Benjamin Franklin Station Washington, D.C.

[4] Blázovics, A., Sárdi, E.; Szentmihályi, K. Váli, L., Takács-Hájos M. and Stefanovits-Bányai, E. (2007). Extreme consumption of Beto vulgaris var. rubra can cause metal ion accumulation in the liver. Acta Biol. Hung., 58(3): 281-6.

[5] Georgiev, V.G.; Weber, J.; Kneschke, E.M.; Denev, P.N.; Bley, T. and Pavlov, A.I (2010). Antioxidant activity and phenolic content of betalain extracts from intact plants and hairy root cultures of the red beetroot Beta vulgaris cv. Detroit dark red. Plant Foods Hum. Nutr., $65,105-111$. 
[6] García-Pérez, F.J, Sendra, E, Lario, Y., Fernández-López, J., Sayas, E. and Pérez- Alvarez, J.A. (2006). Rheology of orange fiber enriched yoghurt. Milchwissenschaft, 61: 55-59.

[7] Aryana, K.J. (2003). Folic acid blended fat free plain set yoghurts. Int. J. Dairy Technol., 56(4): 219-222.

[8] Isolauri E, Rautava S, Kalliomäki M, Kirjavainen P, and Salminen S (2002). Role of probiotics in food hypersensitivity. Curr Opin Allergy Clin Immunol 2: 263-271.

[9] Ravichandran, K., Saw, N. M. M. T., Mohdaly, A. A. A., Gabr, A. M. M., Kastell, A., Riedel, H., Cai, Z., Knorr, D., and Smetanska, I. (2013). Impact of processing of red beet on betalain content and antioxidant activity. Food Res. Int. 50(2), 670-675. http://dx.doi.org/10.1016/j.foodres.2011.07.002.

[10] Amnah, M. A. Alsuhaibani Nutritional (2013). Sensory and Biological Study of Biscuits Fortified With Red Beet Roots. Life Science Journal 2013;10(3).

[11] Campbell, J.A. (1963). Methodology of Protein Evaluation. RAG: Nutr., Document R.101 add. 37 June Meeting, New York.

[12] Devi, R.K. and Sharma, D.K. (2004). Hypolipidemic effect of different extracts of Cleroden droncolebro okianum Walp in normal and high-fat diet fed rats. J. Ethnopharmacol. 90:63-68.

[13] Elleuch, M., Bedigian, D., Roiseux, O., Besbes, S., Blecker, C. and Attia, H. (2011). Dietary fiber and fiber-rich by-products of food processing:Characterisation, technological functionality and commercial applications. Revue of Food Chem., 124, 411-421.

[14] El-Said, M. M., Haggag, H.F., Fakhr El-Din, H. M., Gad, A.S. and Farahat, M. A. (2014). Antioxidant activities and physical properties of stirred yoghurt fortified with pomegranate peel extracts. Annals of Agricultural Sci., Faculty of Agric., Ain Shams Uni., 59(2): 207 212.

[15] El-Houfi, F. B. B. (2015). Extraction and identification of phenolic compounds from agro industrial wastes and there antioxidant efficiency on sunflower oil oxidative stability. Ph.D. Thesis, Department of Food Science Technology, Faculty of Agricalture, Damanhur University, Egypt.

[16] Emun, K., Eyassu, S., Geremew, B. and Solomon, W.K. (2016) Effect of carrot juice and stabilizer on the physicochemical and microbiological properties of yoghurt. LWT - Food Sci. and Technol., 69: 191-196.

[17] Espírito-Santo, A.P., Lagazzo, A., Sousa, A.L.O.P., Perego, P., Converti, A., and Oliveira M. N., (2013). Rheology, spontaneous whey separation, microstructure and sensorial characteristics of probiotic yoghurts enriched with passion fruit fiber. Food Res. Inter., 50:224-231

[18] Enaam S Shokery, Mohamed G El-Ziney*, Asmaa H Yossef and Reda I Mashaly (2017). Effect of Green Tea and Moringa Leave Extracts Fortification on the Physicochemical, Rheological, Sensory and Antioxidant Properties of Set-Type Yoghurt. J Adv Dairy Res, Volume 5, Issue 2.

[19] Eman A. Sadeek, (2011). Protective effect of fresh juice from red beetroot (Beta vulgaris L.) and radish (Raphanus sativus L.) against carbon tetrachloride induced hepatotoxicity in rat models. African J. Biol.Sci., 7(1): 69-84.

[20] Hashim, I.B., Khalil, A.H. and Afifi, H.S. (2009). Quality characteristics and consumer acceptance of yoghurt fortified with date fiber. J. Dairy Sci., 92(11): 5403-5407.

[21] Hassan, L.K., Haggag, H.F., El-Kalyoubi, M.H., Abd EL-Aziz, M. El-Sayed M. M. and Sayed, A.F. (2015). Physico-chemica properties of yoghurt containing cress seed mucilage or guar gum. Annals of Agric. Sci., Fac. of Agric., Ain Shams University, 60 (1):21-28.

[22] Jung Lye Kim1, In Sook Chae1, Young Hee Kang2 and Jung Sook Kang $1 \S$ (2008). Effect of onion and beet on plasma and liver lipids, platelet aggregation, and erythrocyte $\mathrm{Na}$ efflux in simvastatin treated hypercholesterolmic rats. Nutrition Res. and Practice (2008), 2(4), 211-217.

[23] JINGYU YANG, YAN LI, FANG WANG and CHUNFU WU: Hepatoprotective (2010). Effects of apple polyphenols on $\mathrm{CCl} 4$ induced acute liver damage in mice J. Agric. Food Chem., 58 (10), pp. 6525-6531, 2010.

[24] John F. Lechner, Li-Shu Wang, Claudio M. Rocha, Bethany Larue, Cassandra Henry, Colleen M. McIntyre, Kenneth M. Riedl, Steven J. Schwartz, and Gary D. Stoner. (2010). Drinking water with red beet root food color antagonizes esophageal Carcinogenesis in N-Nitro some thylbenzyl amine-Treated Rats. J Med Food 13 (3) 2010, 733 739 .

[25] Kapadia, G.J., M.A. Azuine, G.S. Rao, T. Arai, A. Iida and H.Tokuda, (2011). Cytoxic effect of the red beetroot (beta vulgaris l.) extract compared to doxorubicin (Adriamycin) in the human prostate (pc- 3) and breast (mcf-7) cancer cell lines. Anti-Cancer Agents in Medicinal Chemistry, 11 (3), 280-284

[26] MOHAMED S. ABD. EL-BAKY, and FATMA L. AHMED, (2011) Effect of some fruits and vegetables peels extract on $\mathrm{CCl} 4$ induced hepatic injury in rats. Med. J. Cairo Univ., Vol. 79, No. 1, March 49-57.

[27] Straus, S., Bavec, F., Turinek, M., Slatnar, A., Rozman, C., and Bavec, M. (2012). Nutritional value and economic feasibility of red beetroot (Beta vulgaris L. ssp. vulgaris Rote Kugel) from different production systems. African J. Agric. 1 Res., 7(42), 5653-5660. http://dx.doi.org/10.5897/AJAR12.1519.

[28] Monika Wroblewska*, Jerzy Juskiewicz and Wieslaw Wiczkowski. (2011). Physiological properties of beetroot crisps applied in standard and dyslipidaemic diets of rats. Lipids in Health and Disease 2011, 10:178.

[29] Marina Dello Staffolo, Alicia E. Bevilacqua, Mari, Susana Rodrguez and Liliana Albertengo (2012). Dietary Fiber and Availability of Nutrients: A Case Study on Yoghurt as a Food Model. Chapter 17,455-490.

[30] Hamdy, A.M.; El-Kousey, L.A. and Abdel-Latif, R. (1972). A study in the fermented milk (zabady). Agric., Res., Rev., 50(3): 159-168.

[31] Hegested, D. Mill, R. and Perkins, E. (1941). Salt mixture. J. Biol. Chem., 138:45g.

[32] Naeem M. Rabeh 0(2015). Effect of Red Beetroot (Beta vulgaris L.) And its Fresh Juice Against Carbon Tetrachloride Induced Hepatotoxicity in Rats. World Applied Sciences Journal 33 (6): 931938, 2015.

[33] Komal Kushwahaa Paras Sharmab Yogesh Gata Anil Panghal (2019). Bioactive compounds of beetroot and utilization in food processing industry: A critical review. Food Chem. 272, 30 192-200.

[34] Fernández-García E., McGregor JU (1997). Fortification of sweetened plain yoghurt with insoluble dietary fibre. European Food Research and Technology 1997;204, 433-437.

[35] Johnson, R.; McNutt, P.; MacMahon, S. and Robson, R. (1997). Use of the friedewald formula to estimate LDL-cholesterol in patients with chronic renal failure on dialysis. Clin. Chem. 43: 2183-2184.

[36] Mohammed, A., A. Saleh, A. Majid, A. Mohammed, M. Nazam and R.Syed (2011). Effect of beta vulgaris on cholesterol rich dietinduced hypercholesterolemia inrats. FARMACIA, 59(5):669:678.

[37] Sana S., and Rahila N. (2017). Evaluation and antifalmmatory effect of natural dietary supplement Beta vulgaris (beet root) in animal models of inflammation. Rawal Medical Journal 42.3. 385- 389.

[38] Sumaya-Martínez M.T., Cruz-Jaime S., Madrigal-Santillán E., García-Paredes, J.D. Carĩno-Cortés, R. Cruz-Cansino, N. ValadezVega, C. Martinez-Cardenas, L. Alanís-García, E. (2011). Betalain, acid ascorbic, phenoliccontents and antioxidant properties of purple, red, yellow and white cactuspears, Int. J. Mol. Sci. 12 (2011) 64526468.

[39] Robertson, R., Gracia, C.M.R., O'Grady, M. M. N., Guihéneuf, F., Dagmar, B., Stengel, R., Fitzgerald P. R., Gerald, Kerry, J. F. P. and Stanton, C. (2016). An assessment of the techno-functional and sensory properties of yoghurt fortified with a lipid extract from the microalga Pavlova lutheri. Food Sci. and Emerging Technologies, 40: $63-70$.

[40] Staffolo, M., Bertola, D. N., Martinoa, M. and Bevilacqua, A. (2004). Influence of dietary fiber addition on sensory and rheological properties of yogurt. International Dairy J., 14: 263-268.

[41] Steel, R.G.D. and Torrie, J.H. (1980). Principles and Procedures of Statistics. McGraw., New York.

[42] Suvarna Kim S, Christopher Layton and Bancroft John D. (2013): Bancroft's Theory and Practice of Histological Techniques, 7th Edition.)

[43] Vassilios Raikos, Angela McDonagh, Viren Ranawana, Garry Duthie (2016). Effects on physical stability, texture and sensory attributes / Food Science and Human Wellness 5 (2016) 191-198.

[44] Pal, R., K. Girhepunje, H. Gevariya and N. Thirumoorthy, (2010). Hepatoprotective activity of Beta vulgaris against $\mathrm{CCl} 4$ induced acute hepatotoxicity in rats. Archives of Applied Science Res., 2(1): 14-18.

[45] Rao, L., H. Khizar, L. Yi, E. Karangwa, S.Q. Xia, C.S. Jia and X.M. Zhang (2011). Effect of ultrafiltration and finding adsorbents on the clarification of green tea. J. Food Eng., 102: 321 - 326.

[46] Young, D.S. (2001). Effects of disease on clinical lab tests, 4th ed. AACC. 